\title{
Microsatellite analysis of a sample of Uruguayan Creole bulls (Bos taurus)
}

\author{
Eileen Armstrong ${ }^{1}$, Alicia Postiglioni ${ }^{1}$, Amparo Martínez ${ }^{2}$, Gonzalo Rincón ${ }^{1}$ and José Luis Vega-Pla ${ }^{3}$ \\ ${ }^{l}$ Facultad de Veterinaria, Laboratorio de Análisis Genéticos en Animales Domésticos, Area Genética, \\ Montevideo, Uruguay. \\ ${ }^{2}$ Universidad de Córdoba, Facultad de Veterinaria, Departamento de Genética, Córdoba, España. \\ ${ }^{3}$ Servicio de Cría Caballar y Remonta, Laboratorio de Genética Molecular, Córdoba, España.
}

\begin{abstract}
The Uruguayan Creole cattle genetic reserve consists of a herd of about 600 animals (bulls, cows and calves) located in an indigenous habitat of 650 hectares. In a previous study, a random sample from this herd showed high heterozygosity and a Hardy-Weinberg equilibrium for markers of major genes related to milk production. To study its genetic diversity we genotyped a sample of bulls ( $N=19$ out of 23 for the whole herd) using the PCR reaction with a set of 17 microsatellite markers. Between two and seven different alleles were identified per microsatellite in a total of 73 alleles. The expected mean heterozygosity $(\mathrm{He})$ per locus was between 0.465 and 0.801 , except for microsatellite HEL13 which gave a He value of 0.288 . The expected mean heterozygosity was 0.623 and the polymorphic information content (PIC) was between 0.266 for HEL13 and 0.794 for CSSM66. The genetic diversity found in polymorphic markers in the breeding bulls of this Creole cattle population supports previous genetic analyses using major production genes and indicate that further studies should be carried out on this population to provide data of interest to cattle production.
\end{abstract}

Key words: Uruguayan Creole cattle, genetic diversity, microsatellites.

Received: March 11, 2005; Accepted: August 26, 2005.

\section{Introduction}

Creole cattle were introduced into America in 1493 by the Spanish and Portuguese conquerors, these cattle being considered the product of multiple admixtures of Iberian and other European cattle. The favorable environment into which the cattle were introduced promoted their reproduction and they soon spread through the entire Central and South American continent. Their adaptation to different environments allowed the expression of a high level of genetic variability but currently only few semi-wild Creole cattle populations remain in South America, examples being the Patagonian Creole cattle of Argentina and the Pantaneiro cattle of Brazil (Primo, 1992). Such semi-wild cattle populations are important because they may be a source of hidden alleles which have potential use in breeding programs, a major reason for locating and conserving such herds (Rendo et al., 2004).

The first introduction of cattle into Uruguay was carried out by Hernando Arias de Saavedra at the beginning of the seventeenth century, and later by the Jesuit Missions of

Send correspondence to Alicia Postiglioni. Facultad de Veterinaria, Laboratorio de Análisis Genéticos en Animales Domésticos, Area Genética, Avda. A. Lasplaces 1550, 11600 Uruguay. E-mails: eileen@internet.com.uy; alipos@adinet.com.uy.
Alto Uruguay. By the end of the nineteenth century many commercial cattle breeds were introduced, including Holstein-Friesian, Hereford and Aberdeen Angus, with the aim of improving cattle production and the Uruguayan economy. These introductions reduced the huge population of Creole cattle to small and sparse subpopulations throughout the country and there is now just a single semi-wild population of about 600 head in southeastern Uruguay in an area of about 650 hectares of native woods, ridges and wetlands. In fact, the population of this herd had reached 1000 animals in recent years but had to be adjusted to a more limited area. Arredondo (1958) documented the creation of the population about 70 years ago from a foundation stock consisting of 35 Creole bulls, cows and calves brought from different locations with similar environments.

Genomic studies using random amplified polymorphic DNA (RAPD) on samples of Creole, Hereford and Uruguayan Holstein-Friesian cattle showed particular genetic distances in terms of band sharing frequencies (Hereford - Creole: 0.77; Holstein - Creole: 0.78; Hereford Holstein; 0.81). In spite of possible genetic introgression events from commercial breeds in the past, band sharing frequencies were higher among commercial breeds but 
lower between commercial breeds and Creole cattle, suggesting that the Creole population has developed mainly in reproductive isolation (Rincón et al., 2000).

Preliminary research on a random sample of cattle from the Uruguayan Creole cattle genetic reserve using the CYP21 and BM2113 polymorphic microsatellites and diallelic sequences of interest to dairy production showed genetic equilibrium and high expected heterozygosity $(\mathrm{He}=0.800)$ (Postiglioni, et al., 2002). In the present study of the same population we analyzed only breeding bulls with a set of 17 microsatellites included in the list recommended by the Food and Agricultural Organization (FAO) for genetic diversity studies in domestic animals that justify their conservation as a sustainable genetic resource (ww.fao.org/DAD-IS; www.ri.bbsrc.ac.uk). In this population there are around 600 individuals but only 23 breeding males, so in such a small population it is important to analyze the diversity of the males as a single category because they contribute half of the genetic variability of future generations.

\section{Material and Methods}

\section{Blood samples and markers analyzed}

The population of Uruguayan Creole cattle of San Miguel National Park consists of 23 bulls and about 445 cows and 105 calves of both sexes. Genomic DNA was extracted from blood samples of 19 bulls by the phenolchloroform technique (John et al., 1991). The genomic DNA is stored in the genetic bank of the Genetic Laboratory of Facultad de Veterinaria, Uruguay.

The 17 microsatellites analyzed were all dinucleotidic (Table 1) selected based on the following criteria: inclusion in the microsatellite list proposed by the $\mathrm{FAO} /$ IDAD (Initiative for Domestic Animal Diversity) program and/or the European Union Cattle Diversity Data Base of the bovine diversity project (ww.fao.org/DAD-IS; www.ri. bbsrc.ac.uk); present a high level of polymorphism; are widely used in the bibliography to allow comparative studies with other breeds; are relatively easy to work with and can be genotyped by multiplex reactions; are evenlydistributed throughout bovine genome.

\section{Microsatellite genotyping}

The PCR genotyping of the 17 microsatellite sequences was performed in a final volume of $20 \mu \mathrm{L}$ : $50 \mathrm{ng} \mu \mathrm{L}^{-1}$ genomic DNA, 10X PCR buffer, $2.5 \mathrm{mM} \mathrm{MgCl} 2,2.5 \mathrm{mM}$ dNTPs, $0.15 \mu \mathrm{M}$ primers and $1 \mathrm{U}_{\mu} \mathrm{L}^{-1}$ of Taq polymerase. Amplification was carried out in three multiplex reactions (M1, M2 and M3) using different fluorochromes for similar-sized microsatellites: M1 = BM1314, CSSM66, ILSTS011, INRA37 and ETH10; M2 = BM1818, BM2113, BM8125, INRA32 and MM12; and M3 = HAUT27, HEL13, HEL9, CSRM60, ILSTS006, INRA63 and TGLA227. Amplification was carried out in a PTC 100 thermocycler (MJ Research Inc, USA) using an amplification protocol consisting of denaturalization at $95{ }^{\circ} \mathrm{C}$ for $30 \mathrm{~s}$, followed by 35 cycles of $95^{\circ} \mathrm{C}$ for $30 \mathrm{~s}, 55^{\circ} \mathrm{C}$ for $45 \mathrm{~s}$ and $72{ }^{\circ} \mathrm{C}$ for $30 \mathrm{~s}$, with a final extension at $72{ }^{\circ} \mathrm{C}$ for $30 \mathrm{~min}$. The amplified fragments were separated on $6 \%$ polyacrylamide gel electrophoresis in an ABI377XL automatic sequencer and the gels read using the GENESCAN ANALYSIS v3.2.1 software, the GENOTYPER v2.5 program being used to assign an allele to each detected peak or band (both softwares and sequencer are from Applied Biosystems, Forster city Ca. USA). Allele size was standardized using reference samples distributed by ISAG (International Society of Animal Genetics) for comparison tests.

\section{Statistical analysis}

Allele and genotype frequencies of the 17 microsatellite loci were calculated using GENEPOP v3.1c (updated version of GENEPOP v1.2 described in Raymond and Rousset, 1995) and GENETIX v4.02 (Belkhir et al., 1998), this last program also being used to calculate the expected heterozygosity (He), observed heterozygosity (Ho) and expected unbiased heterozygosity $\left(\mathrm{He}_{\mathrm{u}}\right)$ according to the formula developed by Nei (1973) and Nei and Roychoudhury (1974). The polymorphic information content (PIC) index for each marker was calculated according to Botstein et al. (1980).

\section{Results and Discussion}

Of the 169 alleles described for the markers used (http://www.marc.usda.gov/genome/genome.html) 73 alleles were detected in our sample of bulls. The most polymorphic microsatellites were CSSM66 and TGLA227 with seven alleles, while the least polymorphic was BM8125 with two alleles (Table 2). The level of polymorphism detected in each microsatellite was similar to that stated in the literature (q.v. Table 1). In a study of six native Spanish breeds, Martin-Burriel et al. (1998) also found TGLA227 to be the most polymorphic marker.

Regarding measures of genetic diversity (Table 3), the marker with the highest unbiased heterozygosity was CSSM66, followed by HEL9, TGLA227 and BM2113 while the marker with the lowest unbiased heterozygosity was HEL13, followed by BM8125. With the exception of these last two markers, all the microsatellites showed levels of expected unbiased heterozygosity higher than 0.500 (Table 3). Table 3 also shows the mean heterozygosity for the total sample, the fact that there is a difference between the expected (He) and observed (Ho) heterozygosity suggesting a tendency towards heterozygote deficiency.

The PIC values were between 0.266 for HEL13 and 0.794 for CSSM66 (Table 3). A high PIC value depends on the number and frequency distribution of the alleles measured; markers with PIC values exceeding 0.500 being considered more informative (Botstein et al., 1980). In our 
Table 1 - Description of the 17 molecular markers analyzed.

\begin{tabular}{|c|c|c|c|}
\hline Name $^{1}$ & Chromosome & Primers & Size (bp) \\
\hline BM8125 & 17 & $\begin{array}{l}\text { Forward }=\text { CTCTATCTGTGGAAAAGGTGGG } \\
\text { Reverse }=\text { GGGGGTTAGACTTCAACATACG }\end{array}$ & $109-125$ \\
\hline BM1314 & 26 & $\begin{array}{l}\text { Forward }=\text { TTCCTCCTCTTCTCTCCAAAC } \\
\text { Reverse }=\text { ATCTCAAACGCCAGTGTGG }\end{array}$ & $143-167$ \\
\hline BM1818 & 23 & $\begin{array}{l}\text { Forward }=\text { AGCTGGGAATATAACCAAAGG } \\
\text { Reverse }=\text { AGTGCTTTCAAGGTCCATGC }\end{array}$ & $258-272$ \\
\hline BM2113 & 2 & $\begin{array}{l}\text { Forward }=\text { GCTGCCTTCTACCAAATACCC } \\
\text { Reverse }=\text { CTTCCTGAGAGAAGCAACACC }\end{array}$ & $123-143$ \\
\hline CSSM66 & 14 & $\begin{array}{l}\text { Forward }=\text { ACACAAATCCTTTCTGCCAGCTGA } \\
\text { Reverse }=\text { AATTTAATGCACTGAGGAGCTTGG }\end{array}$ & $180-200$ \\
\hline ETH10 & 5 & $\begin{array}{l}\text { Forward }=\text { GTTCAGGACTGGCCCTGCTAACA } \\
\text { Reverse }=\text { CCTCCAGCCCACTTTCTCTTCTC }\end{array}$ & $212-224$ \\
\hline ILSTS011 & 14 & $\begin{array}{l}\text { Forward }=\text { GCTTGCTACATGGAAAGTGC } \\
\text { Reverse }=\text { CTAAAATGCAGAGCCCTACC }\end{array}$ & $262-276$ \\
\hline INRA032 & 11 & $\begin{array}{l}\text { Forward }=\text { AAACTGTATTCTCTAATAGCAC } \\
\text { Reverse }=\text { GCAAGACATATCTCCATTCCTTT }\end{array}$ & $161-187$ \\
\hline INRA037 & 10 & $\begin{array}{l}\text { Forward }=\text { GATCCTGCTTATATTTAACCAC } \\
\text { Reverse }=\text { AAAATTCCATGGAGAGAGAAAC }\end{array}$ & $112-148$ \\
\hline MM12 & 9 & $\begin{array}{l}\text { Forward }=\text { CAAGACAGGTGTTTCAATCT } \\
\text { Reverse }=\text { ATCGACTCTGGGGATGATGT }\end{array}$ & $105-145$ \\
\hline CSRM60 & 10 & $\begin{array}{l}\text { Forward }=\text { AAGATGTGATCCAAGAGAGAGGCA } \\
\text { Reverse }=\text { AGGACCAGATCGTGAAAGGCATAG }\end{array}$ & $90-110$ \\
\hline HAUT27 & 26 & $\begin{array}{l}\text { Forward }=\text { TTTTATGTTCATTTTTTGACTGG } \\
\text { Reverse }=\text { AACTGCTGAAARCTCCATCTTA }\end{array}$ & $128-156$ \\
\hline HEL13 & 11 & $\begin{array}{l}\text { Forward }=\text { TAAGGACTTGAGATAAGGAG } \\
\text { Reverse }=\text { CCATCTACCTCCATCTTAAC }\end{array}$ & $177-197$ \\
\hline HEL9 & 8 & $\begin{array}{l}\text { Forward }=\text { CCCATTCAGTCTTCAGAGGT } \\
\text { Reverse }=\text { CACATCCATGTTCTCACCAC }\end{array}$ & $143-167$ \\
\hline ILSTS006 & 7 & $\begin{array}{l}\text { Forward }=\text { TGTCTGTATTTCTGCTGTGG } \\
\text { Reverse }=\text { ACACGGAAGCGATCTAAACG }\end{array}$ & 281-299 \\
\hline INRA063 & 18 & $\begin{array}{l}\text { Forward }=\text { ATTTGCACAAGCTAAATCTAACC } \\
\text { Reverse }=\text { AAACCACAGAAATGCTTGGAAG }\end{array}$ & $178-188$ \\
\hline TGLA227 & 18 & $\begin{array}{l}\text { Forward }=\text { CGAATTCCAAATCTGTTAATTTGCT } \\
\text { Reverse }=\text { ACAGACAGAAACTCAATGAAAGCA }\end{array}$ & $76-102$ \\
\hline
\end{tabular}

${ }^{1}$ References: ETH10 = SolinasToldo et al. (1993); CSSM66 = Barendse et al. (1997); MM12 = Mommens et al. (1994); CSRM60 = Moore et al. (1994); HAUT27 = Anon (1999); and all the others from Kappes et al. (1997). bp = basepairs.

study, the highest PIC values were obtained for those markers with a high number of alleles (e.g. BM2113, CSSM66 and TGLA227) or which showed a more homogeneous allele frequency distribution even when the number of alleles detected were low (e.g. ILSTS011, INRA32 and ILSTS006) and for those alleles presenting both of these characteristics (e.g. HEL9).

Our study shows that the microsatellite markers with highest heterozygosity and PIC values were BM2113, CSSM66, HEL9 and TGLA227, which should be included in future genetic diversity studies of this and other cattle populations.

The average diversity levels detected were high $\left(\mathrm{He}=0.623 ; \mathrm{He}_{\mathrm{u}}=0.644 ; \mathrm{Ho}=0.584\right.$; mean $\mathrm{PIC}=0.589$; mean number of alleles per locus: 4.294). If the sample is representative of the population, the observed values may be related to the demographic history of the reserve. To support this idea, a larger sample of the population that includes other age-sex categories should be analyzed.

Uruguayan Creole cattle developed from the admixture of many breeds in a process that generates high levels of genetic diversity (Kantanen et al., 2000). Random mating over four centuries appears to have contributed to maintain a high level of diversity in the population studied, aided by the fact that this population was created from 35 Creole cattle that came from different parts of Uruguay, the fusion of small previously isolated populations being known to result in increased heterozygosity due to a reduction in the frequency of homozygotes (Hartl, 1988).

The heterozygosity detected in this study was similar to that found previously in this population (Rincón et al., 2000; Postiglioni et al., 2002). Our results for Uruguayan 
Table 2 - Marker name, alleles detected (in base pairs) and their frequencies.

\begin{tabular}{|c|c|c|c|c|c|}
\hline $\begin{array}{l}\text { Marker name and } \\
\text { number of alleles (bp) }\end{array}$ & Frequency & $\begin{array}{l}\text { Marker name and } \\
\text { number of alleles (bp) }\end{array}$ & Frequency & $\begin{array}{l}\text { Marker name and } \\
\text { number of alleles (bp) }\end{array}$ & Frequency \\
\hline BM8125 & & BM1314 & & BM1818 & \\
\hline 116 & 0.6316 & 155 & 0.0294 & 260 & 0.2857 \\
\hline \multirow[t]{3}{*}{122} & 0.3684 & 157 & 0.4118 & 262 & 0.1071 \\
\hline & & 159 & 0.4412 & 264 & 0.5357 \\
\hline & & 161 & 0.1176 & 268 & 0.0714 \\
\hline BM2113 & & CSSM66 & & ETH10 & \\
\hline 126 & 0.3611 & 179 & 0.0294 & 213 & 0.0938 \\
\hline 128 & 0.0556 & 181 & 0.2059 & 217 & 0.4375 \\
\hline 134 & 0.1111 & 183 & 0.0882 & 219 & 0.4688 \\
\hline 136 & 0.1389 & 187 & 0.3235 & & \\
\hline 138 & 0.2778 & 189 & 0.1471 & & \\
\hline \multirow[t]{2}{*}{140} & 0.0556 & 195 & 0.0882 & & \\
\hline & & 197 & 0.1176 & & \\
\hline ILSTS011 & & INRA32 & & INRA37 & \\
\hline 264 & 0.1000 & 180 & 0.2727 & 114 & 0.1176 \\
\hline 268 & 0.4000 & 182 & 0.2727 & 126 & 0.0882 \\
\hline 270 & 0.3000 & 184 & 0.4545 & 128 & 0.0294 \\
\hline \multirow[t]{2}{*}{272} & 0.2000 & & & 132 & 0.3824 \\
\hline & & & & 136 & 0.3824 \\
\hline MM12 & & CSRM60 & & HAUT27 & \\
\hline 115 & 0.1053 & 93 & 0.5526 & 140 & 0.0417 \\
\hline 119 & 0.2632 & 97 & 0.1579 & 144 & 0.0417 \\
\hline \multirow[t]{3}{*}{131} & 0.6316 & 99 & 0.0526 & 148 & 0.6250 \\
\hline & & 103 & 0.1842 & 150 & 0.1667 \\
\hline & & 105 & 0.0526 & 154 & 0.1250 \\
\hline HEL13 & & HEL9 & & ILSTS006 & \\
\hline 184 & 0.0417 & 151 & 0.2368 & 289 & 0.5000 \\
\hline 188 & 0.1250 & 159 & 0.2368 & 291 & 0.1071 \\
\hline \multirow[t]{3}{*}{192} & 0.8333 & 161 & 0.1579 & 295 & 0.0714 \\
\hline & & 163 & 0.1579 & 297 & 0.3214 \\
\hline & & 165 & 0.2105 & & \\
\hline INRA063 & & TGLA227 & & & \\
\hline 173 & 0.3529 & 85 & 0.1053 & & \\
\hline 175 & 0.0882 & 89 & 0.3158 & & \\
\hline \multirow[t]{5}{*}{181} & 0.5588 & 91 & 0.0526 & & \\
\hline & & 93 & 0.3421 & & \\
\hline & & 95 & 0.1316 & & \\
\hline & & 97 & 0.0263 & & \\
\hline & & 99 & 0.0263 & & \\
\hline
\end{tabular}

Creole cattle are similar to those from other American Creole and Iberian cattle breeds studied with microsatellite markers from the same FAO and ISAG references lists. For example, Zamorano et al. (1998a) studied Argentinean Creole cattle from Patagonia and found that the expected heterozygosity per locus was between 0.46 and 0.72 while in a different study the same workers (Zamorano et al., 1998b) found an expected heterozygosity of 0.60 for the
Andalusian breed 'Berrenda en Negro', a proposed ancestral breed of American Creole cattle. In an analysis of six Spanish native breeds, Martín-Burriel et al. (1998) found an average expected heterozygosity between 0.56 and 0.68 , depending on the breed. In addition, Rendo et al. (2004) found an expected heterozygosity of between 0.69 and 0.76 in four Western Pyrenean cattle breeds, while a study by Mateus et al. (2004) of 15 Portuguese cattle breeds found 
Table 3 - Marker name, number of alleles, heterozygosity and polymorphic information content (PIC) of the $a$ markers studied.

\begin{tabular}{lccccc}
\hline & & \multicolumn{3}{c}{ Heterozygosity } & \\
\cline { 3 - 4 } Marker name & Number of alleles & Expected $(\mathrm{He})$ & Expected unbiased $\left(\mathrm{He}_{\mathrm{u}}\right)$ & Observed (Ho) & PIC \\
\hline BM8125 & 2 & 0.465 & 0.478 & 0.316 & 0.357 \\
BM1314 & 4 & 0.621 & 0.640 & 0.647 & 0.549 \\
BM1818 & 4 & 0.615 & 0.638 & 0.500 & 0.585 \\
BM2113 & 6 & 0.755 & 0.776 & 0.778 & 0.750 \\
CSSM66 & 7 & 0.801 & 0.825 & 1.000 & 0.794 \\
ETH10 & 3 & 0.580 & 0.599 & 0.563 & 0.493 \\
ILSTS011 & 4 & 0.700 & 0.737 & 0.500 & 0.661 \\
INRA32 & 3 & 0.645 & 0.675 & 0.727 & 0.603 \\
INRA37 & 5 & 0.685 & 0.706 & 0.706 & 0.642 \\
MM12 & 3 & 0.521 & 0.535 & 0.526 & 0.464 \\
CSRM60 & 5 & 0.630 & 0.647 & 0.632 & 0.615 \\
HAUT27 & 5 & 0.563 & 0.587 & 0.417 & 0.539 \\
HEL13 & 3 & 0.288 & 0.301 & 0.333 & 0.266 \\
HEL9 & 5 & 0.794 & 0.815 & 0.737 & 0.781 \\
ILSTS006 & 4 & 0.630 & 0.653 & 0.286 & 0.623 \\
INRA63 & 3 & 0.555 & 0.572 & 0.412 & 0.549 \\
TGLA227 & 7 & 0.751 & 0.771 & 0.842 & 0.743 \\
\hline Mean & 4.294 & 0.623 & 0.644 & 0.584 & 0.589 \\
\hline
\end{tabular}

an average expected heterozygosity of between 0.63 and 0.74 .

However, the heterozygosity found in our sample of Uruguayan Creole bulls is considerably higher in comparison to that found in studies on commercial breeds that used similar microsatellites. For example, Hanslik et al. (2000) found an average expected heterozygosity of 0.43 in the Holstein-Friesian population of the United States and of 0.48 in the original Netherlands population, while MacHugh et al. (1994) detected average heterozygosity levels of between 0.40 and 0.49 in six European commercial breeds (Aberdeen Angus, Charolais, Holstein-Friesian, Hereford, Jersey and Simmental) using a set of 12 microsatellite markers. These studies show that highly selected commercial breeds are much less diverse and more inbred than local breeds, what reinforces the importance of local breeds as reserves of genetic diversity for a sustainable agriculture.

Microsatellites give more exact and unbiased estimations of populational genetic diversity than other molecular markers with less polymorphism (Kantanen et al., 2000; Lirón et al. 2002). Our present analysis contributes to the genetic characterization and conservation management strategies of the Uruguayan Creole cattle population.

In conclusion, the sample of Uruguayan Creole breeding bulls in the genetic reserve showed high levels of genetic diversity. Since the bulls studied represent the male parents of future generations, it should be possible to maintain an adequate level of genetic diversity in the reserve for the next few years. Future population viability analysis (Lacy, 1993) will help determine if this number of males is appropriate for sustaining the development of the reserve. Further analysis of other age-sex categories and of the reserve as a whole will reveal the diversity and genetic structure of the population and will yield the necessary data for achieving characterization and conservation goals.

\section{Acknowledgments}

The authors thank to Sra. Iris Hernández for her technical assistance, Dr. MV. Marcela Silveira and personal of Servicio de Parques del Ejército (SEPAE) for their work and sample collection and Dr. Juan Vicente Delgado of CYTED (Ciencia y Tecnología para el Desarrollo) for partial financial support of the automatic genotyping system. This work was also supported by grants from PEDECIBA (Programa de Desarrollo de las Ciencias Básicas), CSIC (Universidad de la República) and CIDEC (Facultad de Veterinaria).

\section{References}

Arredondo, H (1958) Santa Teresa y San Miguel. La restauración de las fortalezas. La formación de sus parques. Imprenta "El Siglo Ilustrado", Montevideo. Biblioteca Nacional, Montevideo, Uruguay.

Barendse W, Vaiman D, Kemp SJ, Sugimoto Y, Armitage SM, Williams JL, Sun HS, Eggen A, Agaba M, Aleyasin SA, Band M, Bishop MD, Buitkamp J, Byrne K, Collins F, Cooper L, Coppettiers W, Denys B, Drinkwater RD, Easterday 
K, Elduque C, Ennis S, Erhardt G, Ferretti L, Flavin N, Gao Q, Georges M, Gurung R, Harlizius B, Hawkins G, Hetzel J, Hirano T, Hulme D, Jorgensen C, Kessler M, Kirkpatrick BW, Konfortov B, Kostia S, Kuhn C, Lenstra JA, Leveziel H, Lewin HA, Leyhe B, Lil L, Burriel IM, McGraw RA, Miller JR, Moody DE, Moore SS, Nakane S, Nijman IJ, Olsaker I, Pomp D, Rando A, Ron M, Shalom A, Teale AJ, Thieven U, Urquhart BGD, Vage DI, VandeWeghe A, Varvio S, Velmala R, Vikki J, Weikard R, Woodside C, Womack JE, Zanotti M and Zaragoza P (1997) A medium-density genetic linkage map of the bovine genome. Mamm Genome 8:21-28.

Belkhir K, Borsa P, Goudet J, Chikhi L and Bonhomme F (1998) GENETIX, logiciel sous WindowsTM pour la génétique des populations. Laboratoire Génome et Populations, CNRS UPR 9060, Université de Montpellier II, Montpellier, France. http://www.univ-montp2.fr/ genetix/genetix/genetix.htm.

Botstein D, White RL, Skolnick M and Davis RW (1980) Construction of a genetic linkage map in man using restriction fragment length polymorphisms. Am J Hum Genet 32:314331.

Food and Agriculture Organization (FAO) (1999), Domestic Animal Diversity Information System (DAD-IS); http//www. fao.org/dad-is

Hanslik S, Harr B, Brem G and Schlötterer C (2000) Microsatellite analysis reveals substantial genetic differentiation between contemporary New World and Old World Holstein-Friesian populations. Anim Genet 31:31-38.

Hartl DL (1988) A Primer of Population Genetics. 2nd edition. Sinauer Associates Inc., Sunderland, Massachusetts, 305 pp.

John S, Weitzner G, Rozen R and Scriver C (1991) A rapid procedure for extracting genomic DNA from leukocytes. Nucleic Acids Res 19:408.

Kantanen J, Olsaker I, Holm LE, Lien S, Vilkki J, Brusgaard K, Eythorsdottir E, Danell B and Adalsteinsson S (2000) Genetic diversity and population structure of 20 North European cattle breeds. J Hered 91:446-457.

Kappes SM, Keele JW, Stone RT, McGraw RA, Sonstegard TS, Smith TPL, Lopez-Corrales NL and Beattie CW (1997) A second-generation linkage map of the bovine genome. Genome Res 7:235-249.

Lacy RC (1993) Population viability analysis. In: Kreeger T (ed) VORTEX Users Manual. AStochastic Simulation of the Extinction Process. Captive Breeding Specialist Group of the IUCN Species Survival Comission. Chicago, USA, 96 pp.

Lirón JP, Ripoli MV, De Luca JC, Peral-García P and Giovambattista G (2002) Análisis of genetic diversity and population structure in Argentine and Bolivian Creole cattle using five loci related to milk production. Genet Mol Biol 25:413419.

Mac Hugh DE, Loftus RT, Bradley DG, Sharp PM and Cunningham P (1994) Microsatellite DNA variation within and among European cattle breeds. Proc R Soc Lond 256:25-31.

Martín-Burriel I, García-Muro E and Zaragoza P (1998) Genetic diversity analysis of six Spanish native cattle breeds usind microsatellites. Anim Genet 30:177-182.

Mateus JC, Eding H, Penedo MCT and Rangel-Figueiredo MT (2004) Contributions of Portuguese cattle breeds to genetic diversity using marker-estimated kinships. Anim Genet 35:305-313

Mommens GW and Coppieters A (1994) Dinucleotide repeat polymorphism at the bovine MM12E6 and MM8D3 loci. Anim Genet 25:368.

Moore SS and Byrne K (1994) Characterization of 65 bovine microsatellites. Mamm Genome 5:84-90.

Nei M (1973) Analysis of gene diversity in subdivided populations. Proc Natl Acad Sci USA 70:3321-3323.

Nei M and Roychoudhury AK (1974) Sampling variances of heterozygosity and genetic distance. Genetics 76:379-390.

Postiglioni A, Rincón G, Kelly L, Llambí S, Fernandez G, D’Angelo M, Gagliardi G, Trujillo J, de Bethencourt M, Guevara K, Castellano A and Arruga MV (2002) Biodiversidad genética en bovinos Criollos del Uruguay. Análisis con marcadores moleculares. Archivos de Zootecnia 51:195-202.

Primo AT (1992) El ganado bovino ibérico en las Américas: 500 años después. Archivos de Zootecnia 41:421-432.

Raymond M and Rousset F (1995) GENEPOP (version 1.2): Population genetics software for exact tests and ecumenicism. J Hered 86:248-249.

Rendo F, Iriondo M, Jugo BM, Aguirre A, Mazón LI, Vicario A, Gómez M and Estonba A (2004) Analysis of the genetic structure of endangered bovine breeds from the Western Pyrenees using DNA microsatellite markers. Biochem Genet 42:99-108.

Rincón G, D’Angelo M, Gagliardi R, Kelly L, Llambí S and Postiglioni A (2000) Genomic polymorphism in Uruguayan Creole cattle using RAPD and microsatellite markers. Res Vet Sci 69:171-174.

Solinas Toldo S and Fries R (1993) Physically mapped, cosmidderived microsatellite markers as anchor loci on bovine chromosomes. Mamm Genome 4:720-727.

Zamorano MJ, Género ER, Rodero A, Vega Pla JL and Rumiano FJ (1998a) Caracterización genética del ganado bovino Criollo Argentino utilizando microsatélites. Archivos de Zootecnia 47:273-277.

Zamorano MJ, Ruiter J, Rodero A and Vega Pla JL (1998b) Análisis genético de marcadores microsatélites en dos poblaciones de la raza bovina Berrenda en Negro. Archivos de Zootecnia 47:195-200.

Associate Editor: Pedro Franklin Barbosa 